Гаврилюк Оксана Анатольевна,

Муниципальное бюджетное общеобразовательное учреждение

«Средняя общеобразовательная школ № №7» г. Губкинского учитель

технологии

\title{
РАЗВИТИЕ ТВОРЧЕСКИХ СПОСОБНОСТЕЙ \\ ОБУЧАЮЩИХСЯ \\ В КРУЖКЕ «ЭТНО-РУСЬ»
}

\begin{abstract}
Аннотация
Данная статья указывает, что работа кружка «Этно-Русь» декоративно - прикладного творчества способствует расширению кругозора учащихся, повышает общую культуру, знакомит с историей техники и традициями декоративно - прикладного искусства, приучает к вдохновенному труду.

Автор раскрывает работу позволяющих овладеть последовательностью действий, гарантирующих получение запланированного результата в предметно-преобразовательной деятельности на основе использования знаний и умений из основ различных наук.
\end{abstract}

Ключевые слова: креативность, самореализация личности, проектный метод обучения, самовоспитание и раннее профессиональное самоопределение, личная деятельность обучающегося, эмоциональная и социальная значимость.

\footnotetext{
Мы живём в период кризисов политических, социальных, экономических, экологических - и смены ориентиров. Однако самый страшный кризис - нравственный. В качестве основы устойчивости воспринимаются лишь ценности культуры, её достижения, ставшие символом взлёта человеческой мысли, творчества.

О.И.Сгибнева
}

Известные слова о том, что красота спасёт мир, многим кажутся утопией. Но разве мы в конце XX столетия не исчерпали своих надежд изменить мир с помощью войн, экономических успехов, соперничества или науки? Разве не привели эти надежды к международному тупику?

Остается одна нереализованная возможность - построить мир на сознании красоты: красоты природы, красоты человека и человеческих отношений, красоты искусства. 
В наш новый век еще не осуществлен великий идеал полного слияния искусства с жизненными потребностями, как это было в Китае, Египте, Древней Греции, в Западной Европе в Средние века, но мы должны работать и приближать это время, чтобы искусство, а значит, и красота вошли в наши дома.

Одна из задач образования - помочь ребенку открыть самого себя. Показать, что мир существует не только вокруг, но и внутри каждого. И этот мир позволит увидеть прекрасное в самых простых, обыденных вещах: соломке, травинке, кусочке ткани и т.д. [1]

Неотъемлемой характеристикой современного образовательного пространства является творчество, которое рассматривается как непременное условие успешной самореализации личности, позволяющее наиболее эффективно проявлять себя в современном мире, в разнообразных жизненных практиках.

Перед педагогической наукой стоит задача воспитания человека с новым, интеллектуальным уровнем самосознания, способного к концептуальному и креативному мышлению. Проведенный социологический опрос показал, что 94\% учителей европейских школ считают, что креативность - фундаментальный навык, который школа должна развивать, 95,5\% считают, что креативность можно развивать в любой области знания, и $41 \%$ учителей проходили тренинг обучения креативности.

Российские учителя связывают креативность (творческую инициативу) в основном с дисциплинами искусства. Как показывает многолетняя практика, для успешного интеллектуального развития школьников недостаточно наличия хорошо организованной систематической напряженной общеобразовательной работы в школе. Необходимым условием этого является использование научных представлений и методов к проблеме выявления и развития детей. Развитию художественно-эстетического творчества уделяется большое внимание. Использование в развитии ребенка различных видов искусства дает возможность для личностного роста и самоопределения.

Обучающиеся любят музыку, сказку, рисование, лепку, шитьё, вязание на спицах и крючком, лоскутное шитьё, вышивание, и сценические представления.

Дополнительное образование уделяет внимание не только динамике развития способностей, но и воспитанию, самовоспитанию и раннему профессиональному самоопределению, знакомит с миром профессий и ориентирует школьников на работу в различных сферах общественного производства. Выходя за рамки предмета, веду кружок Этно - Русь, который позволяет формировать всестороннее интеллектуальное и эстетическое развитие детей в процессе овладения элементарными приемами различными техниками ДПИ.

Для развития умственных способностей и интереса к знаниям использую на практике следующие методы обучения: 
1. Объяснительно-наглядный (репродуктивный) метод. Этот метод охватывает: демонстрацию, лекцию, изучение литературы, телевизионные передачи.

2. Проблемный метод. Благодаря этому методу учащиеся приобретают навыки логического и критического мышления.

3. Частично-поисковый метод. При этом методе учащиеся получают возможность ознакомиться с определенными моментами научноисследовательской работы, при самостоятельной работе в процессе проектирования.

4. Исследовательский метод, благодаря которому учащиеся постепенно познают принципы и этапы научного исследования, изучают литературу, проверяют гипотезы и оценивают полученные результаты.

5. Метод проектов - это система обучения, гибкая модель организации учебного процесса.

Метод проектов способствует формированию у учащихся адекватной самооценке, поднятию их имиджа в окружающей среде, усилению «я сам», «я сделаю», «я умею».[1]

При реализации дополнительной образовательной общеразвивающей программы использую проектный метод обучения, который, на мой взгляд, является основой методики в образовании. Это интегративное дидактическое средство развития. Отсюда следует, что результаты выполнения индивидуального проекта отражают важные компоненты такие, как:

- способность к инновационной, аналитической, творческой, интеллектуальной деятельности;

- способность постановки цели и формулирования гипотезы исследования, планирования работы, отбора и интерпретации необходимой информации, структурирования аргументации результатов исследования на основе собранных данных, презентации результатов.

Каждый этап работы развивает специфические умения и навыки проектирования:

- формулирование ведущей проблемы и постановка задачи, вытекающей из этой проблемы;

- поиск нужной информации, вычленение и усвоение необходимых знаний из информационного поля;

- проведение исследования (анализ, синтез, выдвижение гипотезы, детализация и обобщение).

Для этого я использую различные виды наглядности: естественную, картинную, объемную и звуковую, символическую и графическую. Под словесной наглядностью использую яркую, образную, живую речь, вызывающую у учащихся конкретные представления. [2]

Во время проведения занятий в кружке «Этно-Русь» обучающийся проходит разные этапы: 
- делать то, что хорошо получается. Тогда испытываешь положительные эмоции, радость, наслаждение от деятельности.

- необходимое повышение уровня оптимальной сложности, в процессе которой развивается не только любимая деятельность, но и более сложная. Поэтому работая над выбором следующего проекта, мы совместно с ребенком принимаем решение усложнить его, повышая уровневую планку, это личная деятельность обучающегося, во время которой он выполняет проект и проявляет творчество. Ценность данной деятельности заключается в том, что она помогает ребёнку осознать важность своего развития и реализовать себя в будущем.

Работа в кружке расширяет кругозор обучающихся, повышает общую культуру, заставляет изучать историю техники и традиции декоративно прикладного творчества, позволяет выявить способности и таланты, приучает к вдохновенному труду. В кружке занимаются от 6 до 15 человек, занятия проводятся регулярно 2 раза в неделю. В тематике кружка в теоретической и практической части, заложены исторические и патриотические аспекты, любовь к Родине, природе. Например, в кружке изготавливали сутажные украшения, русские народные костюмы, сценические костюмы, была создана коллекция по профориентации для начальной школы, а также диаграммы на тематику ВOB, празднование «Масленицы», «Рождество Христово» и т.д. Оформлены картины вышитые крестом и гладью. В классе оборудован музей, где экспонируются работы обучающихся. [2]

Занятие любимым делом приносит ощущение эмоциональной и социальной значимости, формирует желание связать с этой деятельностью свою жизнь, даёт ориентир в мире профессий.

\section{Результативное участие обучающихся в (очных) олимпиадах и конференциях (5-9 классы):}

Муниципальнылй этап Всероссийской олимпиадьл школьников по технологии: 2014- 2020 г.- 14 победителей, 9 призёров;

Региональный этап Всероссийской олимпиады икольников по технологии: 2014-2020- 3 победителя, 2 призера;

Всероссийская олимпиада школьников по технологии: 2014г. - участник;

- победитель проекта «Дизайн костюма»;

- по итогам участия в ВОШ-2014 года включена в список участников поездки по местам Нобеля (Швейцария)

Конференции исследовательских работ икольников:

"Ступень в будущее» - 2020г. муниципальный этап - трое дипломантов 1 степени (очный); региональный этап - трое дипломантов 1 степени г. Новый Уренгой, Лабытнанги.

«Юность. Наука. Культура» 2. Обнинск - 2016г. всероссийский этап - один дипломант I степени (очный) Общероссийской малой академии наук; диплом II степени в командной игре (очный) Общероссийской малой академии наук «Юность. Наука. Культура» 
Российская академия инновационных технологий (заочный) «Юный ученый» г. Москва. - всероссийский этап - 2 дипломанта I степени.

- Диплом I степени Российская академия инновационных технологий Международный творческий конкурс «Будущее в наших руках» Детская исследовательская работа;

- Диплом I степени V Окружной заочный конкурс детских творческих проектов «Мир увлечений» и т.д.

Таким образом, результативное участие в ВОШ, конференциях и различных конкурсах показывает, что обучающиеся выходят на высокий уровень мастерства, у них развивается художественный вкус, чувство прекрасного. И они, как будущие строители, по кирпичику, внесут это чувство прекрасного, в свою работу.

Библиографический список

1. https://infourok.ru/rabochaya-programma-po-kruzhkovoy-rabote-moda-ivremya-klassi-3973937.html

2. https://nsportal.ru/shkola/tekhnologiya/library/2013/09/22/obobshcheniepedagogicheskogo-opyta-po-teme-povyshenie 